\title{
Calcitonin Gene-Related Peptide (CGRP) as a GH Secretagogue in Rat and Human Pituitary Tumoral Cells
}

\author{
Yoshio NAKAMURA, AKIRA SHIMATSU*, HiroYuki MURABE, HaRUo MIZUTA, \\ CHIHIRO IHARA, AND KAZUWA NAKAO
}

Department of Medicine and Clinical Science, and ${ }^{*}$ Department of Laboratory Medicine, Kyoto University Graduate School of Medicine, Kyoto 606-8507, Japan

CALCITONIN gene-related peptide (CGRP), a 37amino-acid neuropeptide identified as a potent vasodilator [1], is widely distributed in the central nervous system. The presence of CGRP and its binding sites has been found in the pituitary [2-4], but its role in regulating pituitary function remains to be determined. In the present study, we investigated the effect of CGRP on the secretion of $\mathrm{GH}$ in vitro by using rat pituitary tumoral cells $\left(\mathrm{GH}_{3}\right.$ cells) and human pituitary adenoma cells.

\section{Materials and Methods}

$\mathrm{GH}_{3}$ cells were purchased from the American Type Culture Collection and grown in Ham's F-10 medium supplemented with $15 \%$ horse serum, $2.5 \%$ fetal calf serum, penicillin $\mathrm{G}(50 \mathrm{U} / \mathrm{ml})$, and streptomycin $(50 \mu \mathrm{g} / \mathrm{ml})$ in a humidified atmosphere of $95 \%$ air and $5 \% \mathrm{CO}_{2}$, as previously described [5]. Human somatotroph adenoma tissues were obtained by transsphenoidal surgery. The adenoma cells were dispersed with $0.25 \%$ trypsin, plated onto poly-L-lysin-coated microplates (about 25,000 cells/well), and cultured for $48 \mathrm{~h}$ in the same medium as $\mathrm{GH}_{3}$ cells. The tumoral cells were incubated with various concentrations of CGRP dissolved in Ham's F-10 medium containing

Correspondence to: Dr. Akira SHIMATSU, Department of Laboratory Medicine, Kyoto University Graduate School of Medicine, 54 Shogoin Kawahara-cho, Sakyo-ku, Kyoto 606-8507, Japan. E-mail: ashmts@kuhp.kyoto-u.ac.jp Key words: Calcitonin gene-related peptide (CGRP), GH secretagogue, $\mathrm{GH}_{3}$ cell, Acromegaly
$0.1 \%$ bovine serum albumin for $4 \mathrm{~h}$. The medium was collected and stored at $-20^{\circ} \mathrm{C}$ until assayed. The concentrations of rat and human GH were measured by specific radioimmunoassay provided by NIDDK and with an immunoradiometric assay kit provided by Daiichi RI Lab, respectively. The results were expressed as the mean \pm SEM.

\section{Results}

The addition of CGRP ( 1 pM-100 nM) evoked GH secretion from $\mathrm{GH}_{3}$ cells in a bell-shaped manner. One hundred $\mathrm{pM}$ of CGRP caused the maximam increase in GH secretion (172 $\pm 14 \%$ of control, $P<0.01$ vs. control: Fig. 1$)$. In a case of human somatotroph adenoma (Case 1), GH secretion was stimulated by CGRP (1-100 $\mathrm{nM})$ in a dose-related manner. In another case (Case 2), both 1 and $100 \mathrm{nM}$ of CGRP evoked GH secretion with the same potency (Fig. 2).

\section{Discussion}

In the present study, we have shown that CGRP significantly stimulated GH secretion from rat and human pituitary tumoral cells in vitro. Previous studies with normal rat pituitary cells have shown that CGRP acted on GH secretion in a biphasic manner, namely $100 \mathrm{pM}$ of CGRP inhibited and $100 \mathrm{nM}$ of CGRP stimulated GH release [6]. These discrepancies may be explained by the different CGRP receptor subtypes and/or different intracellular mechanisms of CGRP action between 


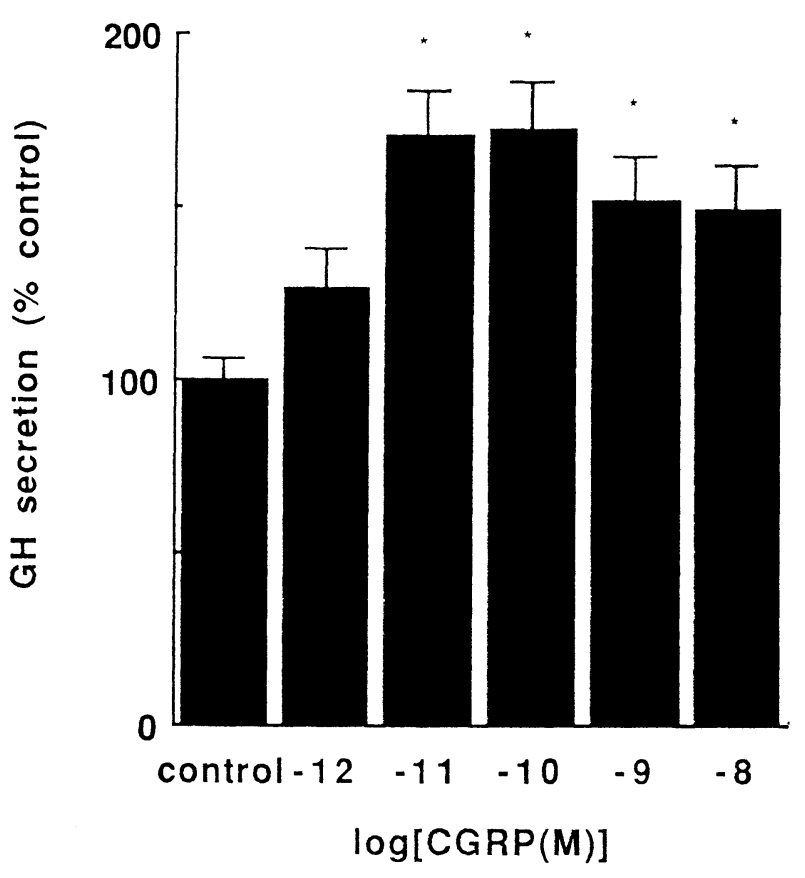

Fig. 1. Effects of various doses of CGRP on GH secretion from rat pituitary cell line, $\mathrm{GH}_{3}$ cells. Means \pm SEM are shown. ${ }^{*} P<0.01$ vs. control. normal and tumoral pituitary cells. It is noteworthy that the effects of CGRP on $\mathrm{GH}$ secretion from $\mathrm{GH}_{3}$ cells were bell-shaped, suggesting that a different mechanism operated when a larger dose of CGRP was used. CGRP present in gonadotrophs of rat and human pituitary gland [7] may be a new member of the $\mathrm{GH}$ secretagogues acting in a paracrine manner.

\section{Acknowledgements}

This work was supported in part by a grant from the Foundation for Growth Science in Japan.

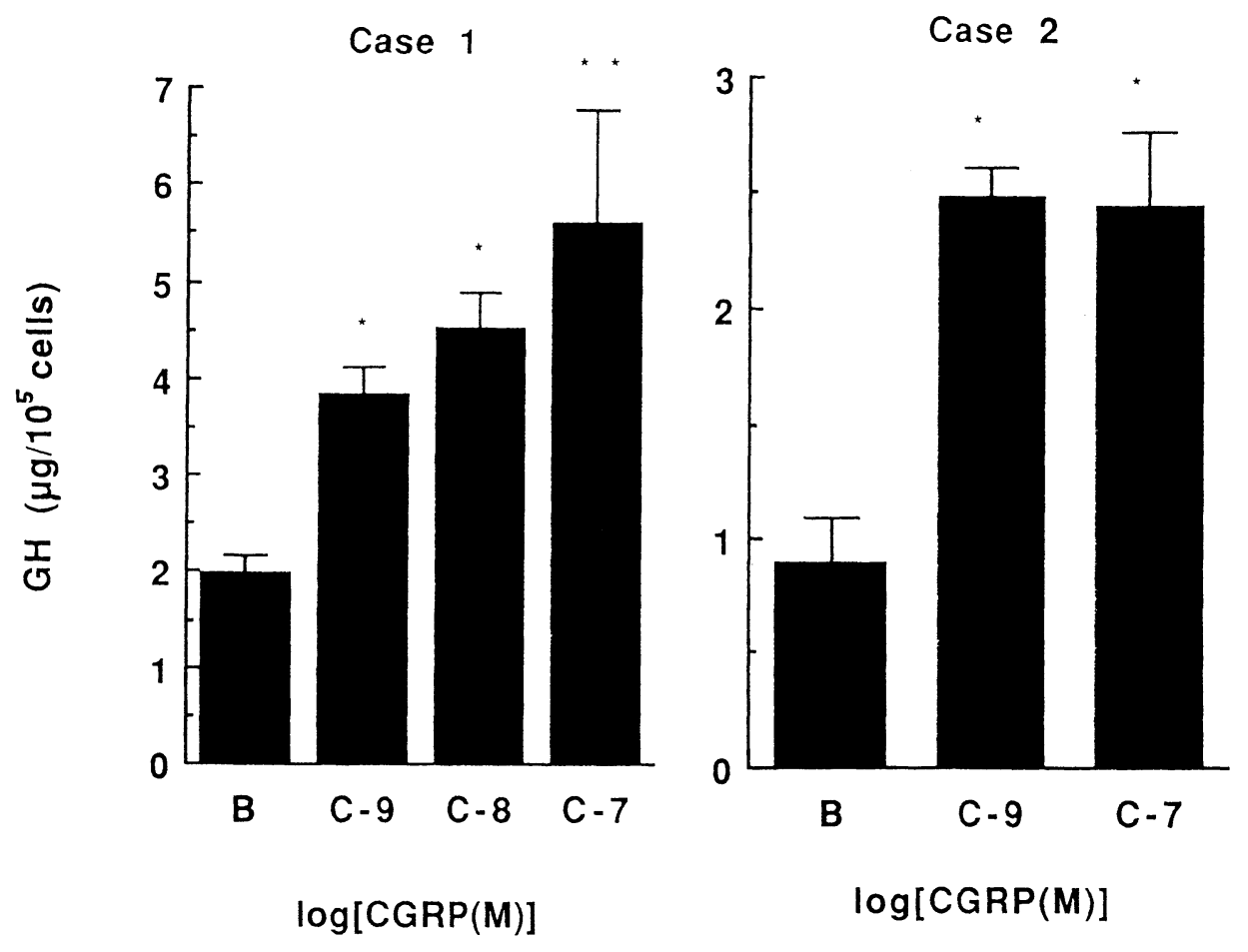

Fig. 2. Effects of CGRP on GH secretion from somatotroph adenoma cells of two acromegalic patients. Means \pm SEM are shown. ${ }^{*} P<0.01,{ }^{* *} P<0.05$ vs. B (control). 


\section{References}

1. Amara AS, Jones V, Rosenfeld MG, Ong ES, Evans RM (1982) Alternative RNA processing in calcitonin gene expression generates mRNAs encoding different polypeptide products. Nature 298: 240-244.

2. Tschopp FA, Henke H, Petermann JB, Tobler PH, Janzer R, Hokfelt T, Lundberg JM, Cuello C, Fischer JA (1985) Calcitonin gene-related peptide and its binding sites in the human central nerve system and pituitary. Proc Natl Acad Sci USA 85: 248-252.

3. Tschopp FA, Tobler PH, Fischer JA (1984) Calcitonin gene-related peptide in the human thyroid, pituitary, and brain. Mol Cell Endocrinol 36: 53-57.

4. Wimalawansa SJ, Emson PC, Macintyre I (1987) Regional distribution of calcitonin gene-related peptide and its specific binding sites in rats with particular reference to the nerve system. Neuroendocrinology 46: 131-136.

5. Tashjan AH Jr. (1979) Clonal strains of hormoneproducing pituitary cells. Meth Enzymol 58: 527-535

6. Fahim A, Rettori V, McCann SM (1990) The role of calcitonin gene-related peptide in the control of growth hormone and prolactin release. Neuroendocrinology 51: 688-693.

7. Steel JH, Gon G, Giaid A, O'halloran J, Emson MA, Van Noorden S, Ghatei MA, Jones PM, Amara SG, Ishikawa H, Bloom SR, Polak JM (1992) Localization of calcitonin gene-related peptide in the rat and human pituitary gland using immnocytochemistry and in situ hybridization. Ann NY Acad Sci 657: 135-154. 